\title{
THE INFLUENCE OF FARMING SYSTEMS ON THE TECHNOLOGICAL QUALITY OF GRAIN AND FLOUR CULTIVARS OF WINTER WHEAT
}

\section{WPŁYW SYSTEMÓW GOSPODAROWANIA NA JAKOŚĆ TECHNOLOGICZNA ZIARNA I MAQKI ODMIAN PSZENICY OZIMEJ}

\author{
Department of Agronomy, West Pomeranian University of Technology, Szczecin, Poland
}

\begin{abstract}
Streszczenie. Materiał do badań stanowiło ziarno odmian pszenicy ozimej pochodzące z doświadczeń polowych realizowanych w latach 2009-2010 przez Krajowy Ośrodek Badawczy Meklemburgii i Pomorza Przedniego (LFA) w miejscowości Gülzow (Niemcy). Pierwszym czynnikiem był system gospodarowania (konwencjonalny, ekologiczny), a drugim czynnikiem były odmiany pszenicy ozimej (Akteur, Adler, Discus i Hermann). Oznaczono cechy fizyczne ziarna, cechy jakościowe oraz właściwości reologiczne określane na farinografie. Zastosowanie konwencjonalnego i ekologicznego systemu uprawy nie miało znaczącego wpływu na cechy fizyczne ziarna pszenicy. Ziarno pszenicy pochodzące z konwencjonalnego systemu uprawy charakteryzowało się lepszą jakością niż ziarno z systemu ekologicznego. Istotnie większe wartości odnotowano w przypadku zawartości białka, ilości glutenu, rozpływalności glutenu i wskaźnika sedymentacji, z wyjątkiem liczby opadania, i indeksu gluten. Zastosowanie systemu konwencjonalnego wpłynęło na uzyskanie korzystniejszych wartości cech farinograficznych w porównaniu z systemem ekologicznym. Wyjątek stanowiła wodochłonność mąki dla której nie stwierdzono istotnych różnic. Najlepszą jakością ziarna i mąki charakteryzowały się odmiany Akteur i Adler, a najgorszą - odmiana Hermann.
\end{abstract}

Key words: winter wheat, conventional system production, ecological system production, cultivars, quality of grain and flour.

Słowa kluczowe: pszenica ozima, konwencjonalny system produkcji, ekologiczny system produkcji, odmiany, jakość ziarna i mąki.

\section{INTRODUCTION}

Common wheat is of the greatest economic importance among cereals (Triticum aestivum ssp. vulgare) (Cacak-Pietrzak et al. 2013). It contains nutrients that are essential in the human diet (Adams et al. 2002; Kihlberg et al. 2004; Shewry 2009; Kong et al. 2013). The economic value of winter wheat varieties is determined by the yield size and its quality. These parameters allow to determine direction of the wheat grain that can be used for different purposes, e.g. for animal feed, for processing in the milling industry, or for bakery products (bread, biscuits), as well as for the production of pasta and groats (Podolska 2007). Grain

Corresponding author - Adres do korespondencji: Magdalena Sobolewska, Departament of Agronomy, West Pomeranian University of Technology, Szczecin, Papieża Pawła VI 3, 71-459 Szczecin, Poland, e-mail: magdalena.sobolewska@zut.edu.pl 
yield and its technological quality depend mainly on: habitat factors, varietal characteristics and applied agricultural technology, as well as protein content (Krejčírová et al. 2006; Woźniak 2006; Al-Saleh and Brennan 2012; Czubacka and Rachoń 2012; Smatanová and Lacko-Bartošová 2012; Harasim and Wesołowski 2013). Nitrogen fertilization is also important in shaping the yield and quality traits of grain (Budzyński et al. 2004; Chrzanowska-Drożdż et al. 2004; Woźniak and Gontarz 2005; Alley et al. 2009). Increasing doses of nitrogen cause the increase in the yield and quality parameters of grain and flour (protein, gluten, sedimentation value ratio), as well as the improvement of farinographic features (Kocoń 2005; Podolska et al. 2005a).

The difference between organic and conventional production system is the lack of mineral fertilizers and chemical pesticides in the former. Wheat grain from organic farming differs in its quality from that produced in conventional farms (Krejčírová et al. 2007). Protein content and quality of gluten in wheat are the main differences in the resulting grain from different farming systems (Krejčířová et al. 2006). According to Mazurkiewicz (2005), baking value of organic wheat flour is lower as compared to the conventional one. The aim of the study was to determine the extent to which the ecological and conventional systems have an impact on the technological value of winter wheat grain and the reaction of studied varieties towards farming systems.

\section{MATERIAL AND METHODS}

Material to study consisted of winter wheat grain originating from the field experiments realized in 2009-2010 by National Research Center for Mecklenburg-West Pomerania (LFA) in Gülzow, Germany. The experiments were performed on a light soil of light to heavy loamy sand composition, humus content of $1.4 \%$, and $\mathrm{pH} 6.0-6.5$ (slightly acidic). The first factor was a farming system (conventional, organic) and the second factor consisted of winter wheat varieties (Akteur, Adler, Discus and Hermann). Following operations were applied in conventional farming system: nitrogen fertilization $\left(210 \mathrm{~kg} \cdot \mathrm{ha}^{-1}\right), \mathrm{S}\left(40 \mathrm{~kg} \cdot \mathrm{ha}^{-1}\right), \mathrm{P}_{2} \mathrm{O}_{5}\left(50 \mathrm{~kg} \cdot \mathrm{ha}^{-1}\right), \mathrm{K}_{2} \mathrm{O}$ $\left(200 \mathrm{~kg} \cdot \mathrm{ha}^{-1}\right), \mathrm{MgO}\left(353 \mathrm{~kg} \cdot \mathrm{ha}^{-1}\right)$, as well as $\mathrm{CaO}\left(588 \mathrm{~kg} \cdot \mathrm{ha}^{-1}\right)$. In addition, during vegetation, plants were sprayed with herbicides (Maliku, Hoechstar), fungicides (Input, Juwel), and growth regulators (CCC 720, Modus). The applied doses were consistent with German recommendations for the winter wheat growing. Grass mixture was the forecrop in organic and conventional production. Mineral fertilizers and chemical pesticides were not used in organic farming. The varieties were classified into the following classes of quality: Akteur, Adler - elite (E), Discus - quality (A) and Hermann - forage (C). The plot area in the field experiment was $25 \mathrm{~m}^{2}$, while number of replicates $n=4$. Analyses were carried out in two replicates to verify the reproducibility of results.

Following analyses were performed:

The thousand grain weight determination was made according to PN-EN ISO 520 : 2011E. Clean material was placed in an automatic seed counter and $4 \times 250$ seeds were counted and weighed to the nearest $0.1 \mathrm{~g}$. According to PN-EN ISO 7971-1:2010P, the loose density was determined. Grains were fractionated by means of PN-EN ISO 5223:2016-02E using Sortimat Pfeiffer Mess - und Prüfgeräte device with sieves of mesh dimensions from 1.8 to 
$2.8 \mathrm{~mm}$, and values from sieves 1.8 to 2.2 were summed up. Determination of sedimentation number was carried out in accordance to PN-EN ISO 3093:2010E. Purified grain was ground using Perten hammer-type grinder LAB MILL type 120. In order to make the a-amylase activity analysis, SWD-SZ type Sadkiewicz device was applied, in which sedimentation number measurement can be performed by means of Hagberg-Perten method. Grain milling was carried out on 6-cylinder laboratory mill produced at the Research Institute of Bakery Industry in Bydgoszcz. The resulting flour was sieved through the laboratory sieve in order to obtain the appropriate fraction for each analysis on sieves of appropriate mesh diameter (265 $\mu \mathrm{m}$ - to farinographic tests, $230 \mu \mathrm{m}$ - to determine the quality and quantity of gluten, $150 \mu \mathrm{m}$ - to determine the rate of sedimentation). Protein content was determined in accordance with PN-EN ISO 20483 : 2014-02P. Calculated nitrogen to protein ratio was 5.7. Determinations of gluten and Index Gluten were made based on PN-EN ISO 21415-2 : 2015-12E applying Gluten Index Perten device. Sedimentation rate was determined according to PN-EN ISO 5529 : 2010E. The analysis was performed on a device consisting of the measuring panel and shaker of SWD-89 Sadkiewicz type. Analysis of farinographic properties of a dough was carried out using Farinograph Brabender device equipped with head of type 50 according to PN-EN ISO 5530-1 : 2015-01. Following parameters were tested: water absorption of flour, dough development time and stability, and softening degree after 10 minutes.

The results were subjected to statistical analysis using the two-factor variance analysis in a completely randomized blocks pattern. Calculations were made with the use of Anal War 4.3 software (F. Rudnicki, Unicersity of Science and Technology, Bydgoszcz, Poland), taking the average values from research years as the replications. The confidence semi-intervals were calculated using Tukey's test at a significance level of 0.05 .

\section{RESULTS AND DISCUSSION}

Results concerning the physical characteristics of the grain are shown in Table 1. The use of a conventional cultivation system resulted in a higher thousand grain weight than in the case of the organic system. The difference in values of the analyzed trait was significant and amounted to $6.4 \mathrm{~g}$. A similar regularity was indicated in the test results by Mazurkiewicz (2005) and Makowska et al. (2008). Results from earlier studies by Wacławowicz et al. (2005) indicate the lack of a significant impact of the farming system on that trait. However Stankowski et al. (2008) reported a decrease in the thousand grain weight due to the influence of elevated nitrogen dose. Kasprzak and Wirkijowska (2013) proved that with a reduced content of thousand grain weight in the organic cultivation system, a decrease of grain milling parameters occurred. Therefore, to determine this parameter has become an important feature of winter wheat, which indicates its suitability for food industries.

In contrast, the loose density of grain was similar in organic and conventional systems, and this difference was as small as $0.5 \mathrm{~g}$. The elite and quality varieties had higher value of discussed characteristics as compared with the other ones belonging to the lower class. A similar situation was presented in studies by Kasprzak and Wirkijowska (2013). The share of grain fraction was not significantly differentiated due to the use of studied cropping systems. 
Table 1. The influence of production system on physical properties of winter wheat grain Tabela 1. Wpływ systemu uprawy na cechy fizyczne ziarna pszenicy ozimej

\begin{tabular}{|c|c|c|c|c|}
\hline \multirow{2}{*}{$\begin{array}{l}\text { Quality parametr } \\
\text { Cechy }\end{array}$} & \multicolumn{2}{|c|}{$\begin{array}{c}\text { Production system } \\
\text { Systemy produkji }\end{array}$} & \multirow{2}{*}{$\begin{array}{l}\text { Average } \\
\text { Średnia }\end{array}$} & \multirow{2}{*}{$\begin{array}{l}\mathrm{NIR}_{0,05} \\
\mathrm{LSD}_{0,05}\end{array}$} \\
\hline & $\begin{array}{c}\text { organic } \\
\text { ekologiczny }\end{array}$ & $\begin{array}{c}\text { conventional } \\
\text { konwencjonalny }\end{array}$ & & \\
\hline $\begin{array}{l}\text { Thousand grain weight } \\
\text { Masa tysiąca ziaren [g] }\end{array}$ & 39.70 & 46.10 & 42.90 & 3.12 \\
\hline $\begin{array}{l}\text { Test weight } \\
\text { Gęstość ziarna w stanie } \\
\text { zsypnym }\left[\mathrm{kg} \cdot \mathrm{hl}^{-1}\right]\end{array}$ & 77.30 & 76.80 & 77.00 & ns. \\
\hline $\begin{array}{l}\text { Grain fraction }<2,2 \mathrm{~mm} \\
\text { Frakcje ziarna }<2,2 \mathrm{~mm}[\%]\end{array}$ & 2.78 & 2.42 & 2.60 & ns. \\
\hline $\begin{array}{l}\text { Grain fraction } 2.2-2.5 \mathrm{~mm} \\
\text { Frakcje ziarna } 2,2-2,5 \mathrm{~mm}[\%]\end{array}$ & 8.85 & 7.79 & 8.32 & ns. \\
\hline $\begin{array}{l}\text { Grain fraction } 2.5-2.8 \mathrm{~mm} \\
\text { Frakcje ziarna } 2,5-2,8 \mathrm{~mm}[\%]\end{array}$ & 28.60 & 28.20 & 28.40 & ns. \\
\hline $\begin{array}{l}\text { Grain fraction }>2.8 \mathrm{~mm} \\
\text { Frakcje ziarna }>2,8 \mathrm{~mm}[\%]\end{array}$ & 60.00 & 61.60 & 60.80 & ns. \\
\hline
\end{tabular}

ns. - non significant - nieistotny.

Values of the quality characteristics underwent remarkable changes when using conventional system as compared to the organic one, except for the falling number and index gluten. The protein content increased by $2.0 \%$, gluten content by $7.8 \%$, and the value of sedimentation rate by $15.0 \mathrm{ml}$ (Table 2). It was found, however, the increase in the gluten flowability from 0.51 to $1.34 \mathrm{~mm}$. Grain and flour quality traits are much more variable under the influence of fertilization, in which nitrogen fertilization is very important (Stankowski et al. 2008; Rachoń and Szumiło 2009; Knapowski et al. 2010). In the studied cultivation systems, the largest difference was the lack of mineral nitrogen fertilization in organic system as compared to the conventional one. The literature data indicate a significant impact of the total protein content on technological value of grain and flour (Kocoń 2005; Stankowski et al. 2008; Rachoń and Szumiło 2009; Knapowski et al. 2010; Cacak-Pietrzak et al. 2013). Our results confirm a significant effect of the farming system on protein content, wet gluten content and gluten softness.

Table 2. The influence of production system on quality properties of winter wheat grain and flour Tabela 2. Wpływ systemu uprawy na cechy jakościowe ziarna i mąki pszenicy ozimej

\begin{tabular}{|c|c|c|c|c|}
\hline \multirow{2}{*}{$\begin{array}{l}\text { Quality parametr } \\
\text { Cechy }\end{array}$} & \multicolumn{2}{|c|}{$\begin{array}{l}\text { Production system } \\
\text { Systemy produkcji }\end{array}$} & \multirow{2}{*}{$\begin{array}{l}\text { Average } \\
\text { Średnia }\end{array}$} & \multirow{2}{*}{$\begin{array}{l}\mathrm{NIR}_{0,05} \\
\mathrm{LSD}_{0,05}\end{array}$} \\
\hline & $\begin{array}{c}\text { organic } \\
\text { ekologiczny }\end{array}$ & $\begin{array}{c}\text { conventional } \\
\text { konwencjonalny }\end{array}$ & & \\
\hline $\begin{array}{l}\text { Falling number } \\
\text { Liczba opadania }[\mathrm{s}]\end{array}$ & 275.00 & 214.00 & 244.00 & ns. \\
\hline $\begin{array}{l}\text { Crude protein content } \\
\text { Zawartość białka [\%] }\end{array}$ & 11.60 & 13.60 & 12.60 & 0.61 \\
\hline $\begin{array}{l}\text { Gluten content } \\
\text { llość glutenu [\%] }\end{array}$ & 23.20 & 31.00 & 27.10 & 3.07 \\
\hline $\begin{array}{l}\text { Gluten softness } \\
\text { Rozpływalność glutenu [mm] }\end{array}$ & 0.51 & 1.34 & 0.93 & 0.68 \\
\hline $\begin{array}{l}\text { Index gluten } \\
\text { Indeks gluten }\end{array}$ & 93.80 & 93.40 & 93.60 & ns. \\
\hline $\begin{array}{l}\text { Rate of sedimentation } \\
\text { Wskaźnik sedymentacji [ml] }\end{array}$ & 17.00 & 32.00 & 24.50 & 2.13 \\
\hline
\end{tabular}

ns. - non significant - nieistotny. 
Influence of conventional cultivation system as compared to the organic one was positive for all farinographic characteristics (Table 3). Waterabsorption of flour, dough development time, and dough stability increased, while dough softening degree decreased. In other own study, water absorption was in the range of $54 \%$ for conventional and $52 \%$ for organic system. Literature data indicate similar values of the discussed feature (Krawczyk et al. 2008a, b; Al-Saleh and Brennan 2012; Stępniewska 2013). Higher levels of this trait, as compared to the own study for conventional system, were reported by Kocon (2005) and Podolska et al. (2005b). Inverse relationship was observed by Cacak-Pietrzak et al. (2014): based on the tests, higher water absorption of flour originating from organic farm, was determined. In the literature, there are some information on higher values of development time and stability as compared with those achieved in own study (Krawczyk et al. 2008b). However Podolska et al. (2005b) reported lower softening degree for winter wheat grain.

Table 3. The influence of production system on rheological properties of winter wheat flour and dough Tabela 3. Wpływ systemu uprawy na reologiczne właściwości mąki i ciasta z pszenicy ozimej

\begin{tabular}{|c|c|c|c|c|}
\hline \multirow{2}{*}{$\begin{array}{l}\text { Quality parametr } \\
\text { Cechy }\end{array}$} & \multicolumn{2}{|c|}{$\begin{array}{l}\text { Production system } \\
\text { System produkcji }\end{array}$} & \multirow{2}{*}{$\begin{array}{l}\text { Average } \\
\text { Średnia }\end{array}$} & \multirow{2}{*}{$\begin{array}{l}\mathrm{NIR}_{0,05} \\
\mathrm{LSD}_{0,05}\end{array}$} \\
\hline & $\begin{array}{c}\text { organic } \\
\text { ekologiczny }\end{array}$ & $\begin{array}{c}\text { conventional } \\
\text { konwencjonalny }\end{array}$ & & \\
\hline $\begin{array}{l}\text { Waterabsorption } \\
\text { Wodochłonność [\%] }\end{array}$ & 52.00 & 53.70 & 52.80 & ns. \\
\hline $\begin{array}{l}\text { Development time } \\
\text { Czas rozwoju [min] }\end{array}$ & 1.60 & 2.63 & 2.11 & 0.77 \\
\hline $\begin{array}{l}\text { Stability } \\
\text { Stabilność [min] }\end{array}$ & 2.20 & 4.83 & 3.52 & 1.15 \\
\hline $\begin{array}{l}\text { Degree of softening after } 10 \mathrm{~min} \\
\text { Stopień rozmiękczenia po } 10 \mathrm{~min} \text { (FU) }\end{array}$ & 96.50 & 73.90 & 85.20 & 21.33 \\
\hline
\end{tabular}

ns. - non significant - nieistotny.

Physical properties of the grain of experimentally tested varieties were significantly different (Table 4). Adler variety was characterized by a higher weight of 1000 grains, while the lowest - Discus cv. The highest values of loose grain density and the share of grain fractions $>2.8 \mathrm{~mm}$ were shown by Akteur and Discus varieties. Similar regularity was pointed out in their research by Kasprzak and Wirkijowska (2013).

Table 4. The influence of cultivars on physical properties of winter wheat grain Tabela 4. Wpływ odmian na cechy fizyczne ziarna pszenicy ozimej

\begin{tabular}{|c|c|c|c|c|c|}
\hline \multirow{2}{*}{$\begin{array}{l}\text { Quality parametr } \\
\text { Cechy }\end{array}$} & \multicolumn{4}{|c|}{$\begin{array}{l}\text { Cultivar of winter wheat } \\
\text { Odmiany pszenicy ozimej }\end{array}$} & \multirow{2}{*}{$\begin{array}{l}\mathrm{NIR}_{0,05} \\
\mathrm{LSD}_{0,05}\end{array}$} \\
\hline & Akteur & Adler & Discus & Hermann & \\
\hline $\begin{array}{l}\text { Thousand grain weight } \\
\text { Masa tysiąca ziaren [g] }\end{array}$ & 40.80 & 51.30 & 38.90 & 40.50 & 4.49 \\
\hline $\begin{array}{l}\text { Test weight } \\
\text { Gęstość ziarna w stanie zsypnym }\left[\mathrm{kg} \cdot \mathrm{hl}^{-1}\right]\end{array}$ & 79.30 & 76.80 & 79.90 & 72.20 & 6.98 \\
\hline $\begin{array}{l}\text { Grain fraction }<2.2 \mathrm{~mm} \\
\text { Frakcje ziarna }<2,2 \mathrm{~mm}[\%]\end{array}$ & 1.86 & 1.65 & 3.06 & 3.84 & 1.76 \\
\hline $\begin{array}{l}\text { Grain fraction } 2.2-2.5 \mathrm{~mm} \\
\text { Frakcje ziarna } 2,2-2,5 \mathrm{~mm}[\%]\end{array}$ & 6.60 & 7.13 & 7.41 & 12.16 & 4.58 \\
\hline $\begin{array}{l}\text { Grain fraction } 2.5-2.8 \mathrm{~mm} \\
\text { Frakcje ziarna } 2,5-2,8 \mathrm{~mm}[\%]\end{array}$ & 25.90 & 24.50 & 30.60 & 32.40 & 4.21 \\
\hline $\begin{array}{l}\text { Grain fraction }>2.8 \mathrm{~mm} \\
\text { Frakcje ziarna }>2,8 \mathrm{~mm}[\%]\end{array}$ & 65.70 & 66.70 & 59.00 & 51.80 & 7.96 \\
\hline
\end{tabular}

ns. - non significant - nieistotny. 
The quality differentiation between the varieties was not very large (Table 5). Significant differences were found in the sedimentation number, sedimentation index and index gluten. Akteur cv. was characterized by the highest sedimentation number, while Hermann cv. - by the lowest. Similar values of the analyzed characteristics that may indicate a classification of wheat grain to elite group (over 300 seconds), were obtained in studies conducted by Krawczyk et al. (2008a), Al-Saleh and Brennan (2012), Weber (2013), as well as Murawska et al. (2014). The other ones (Discus and Adler cv.) showed similar level of 248-250 s. Value of the sedimentation number is a guarantee of obtaining the high-quality flour, which should be around 200-300 seconds (mean amylolytic activity) (Mazurkiewicz 2005; Cacak-Pietrzak et al. 2014). Similar amylolytic activity was found in literature (Podolska et al. 2005b; Ceglińska et al. 2006, 2012; Krawczyk et al. 2008b; Knapowski et al. 2010; Stępniewska 2013; Cacak-Pietrzak et al. 2014).

Table 5. The influence of cultivars on quality properties of winter wheat grain and flour Tabela 5. Wpływ odmian na cechy jakościowe ziarna i mąki z pszenicy ozimej

\begin{tabular}{|c|c|c|c|c|c|}
\hline \multirow{2}{*}{$\begin{array}{l}\text { Quality parametr } \\
\text { Cechy }\end{array}$} & \multicolumn{4}{|c|}{$\begin{array}{l}\text { Cultivar of winter wheat } \\
\text { Odmiany pszenicy ozimej }\end{array}$} & \multirow{2}{*}{$\begin{array}{l}\mathrm{NIR}_{0,05} \\
\mathrm{LSD}_{0,05}\end{array}$} \\
\hline & Akteur & Adler & Discus & Hermann & \\
\hline $\begin{array}{l}\text { Falling number } \\
\text { Liczba opadania [s] }\end{array}$ & 302.00 & 248.00 & 250.00 & 177.00 & 29.70 \\
\hline $\begin{array}{l}\text { Crude protein content } \\
\text { Zawartość białka [\%] }\end{array}$ & 12.80 & 13.20 & 12.40 & 12.20 & ns. \\
\hline $\begin{array}{l}\text { Gluten content } \\
\text { Ilość glutenu [\%] }\end{array}$ & 28.60 & 28.40 & 27.20 & 24.10 & ns. \\
\hline $\begin{array}{l}\text { Gluten softness } \\
\text { Rozpływalność glutenu [mm] }\end{array}$ & 1.15 & 0.58 & 0.70 & 1.28 & ns. \\
\hline $\begin{array}{l}\text { Index gluten } \\
\text { Indeks gluten }\end{array}$ & 100.00 & 98.50 & 93.50 & 82.30 & 13.17 \\
\hline $\begin{array}{l}\text { Rate of sedimentation } \\
\text { Wskaźnik sedymentacji [ml] }\end{array}$ & 29.00 & 28.50 & 21.40 & 19.00 & 4.22 \\
\hline
\end{tabular}

ns. - non significant - nieistotny.

A comparison of the water absorption capacity of flour, dough development time, and its stability (Table 6) shows that only Hermann cv. was characterized by low values of these characteristics. The dough development time was similar in all other three varieties, regardless of the quality class. In the case of dough stability, the best varieties were Akteur and Adler cv. For this feature, an interaction between varieties and cultivation systems was also observed (Fig. 1,2). While in the organic system of growing, the dough stability was similar at all varieties, an increase of 5.15 minutes for Akteur cv., 3.45 minutes for Adler cv., and 201 minutes for Discus cv., occurred in conventional system. Also in the case of dough softening, varieties belonging to a higher technological value (Akteur, Adler) were better. It indicates that varieties of better quality can better respond rather to the organic than conventional cultivation. 
Table 6. The influence of cultivars on rheological properties of winter wheat flour and dough Tabela 6. Wpływ odmian na reologiczne właściwości mąki i ciasta z pszenicy ozimej

\begin{tabular}{lrrrrr}
\hline \multirow{2}{*}{$\begin{array}{l}\text { Quality parametr } \\
\text { Cechy }\end{array}$} & \multicolumn{3}{c}{$\begin{array}{c}\text { Cultivar of winter wheat } \\
\text { Odmiany pszenicy ozimej }\end{array}$} & $\begin{array}{c}\text { NIR } \\
\text { LSD }_{0,05}\end{array}$ \\
\cline { 2 - 6 } & Akteur & Adler & Discus & Hermann & \\
\hline $\begin{array}{l}\text { Waterabsorption } \\
\text { Wodochłonność [\%] }\end{array}$ & 54.50 & 54.30 & 53.50 & 49.00 & 3.33 \\
\hline $\begin{array}{l}\text { Development time } \\
\text { Czas rozwoju [min] }\end{array}$ & 2.38 & 2.55 & 2.30 & 1.23 & \multirow{2}{*}{ ns. } \\
\hline $\begin{array}{l}\text { Stability } \\
\text { Stabilność [min] }\end{array}$ & 4.93 & 4.28 & 3.55 & 1.30 & 2.28 \\
\hline $\begin{array}{l}\text { Degree of softening after 10 min (FU) } \\
\text { Stopień rozmiękczenia po 10 min }\end{array}$ & 64.80 & 64.80 & 77.80 & 133.50 & 42.24 \\
\hline
\end{tabular}

ns. - non significant - nieistotny.

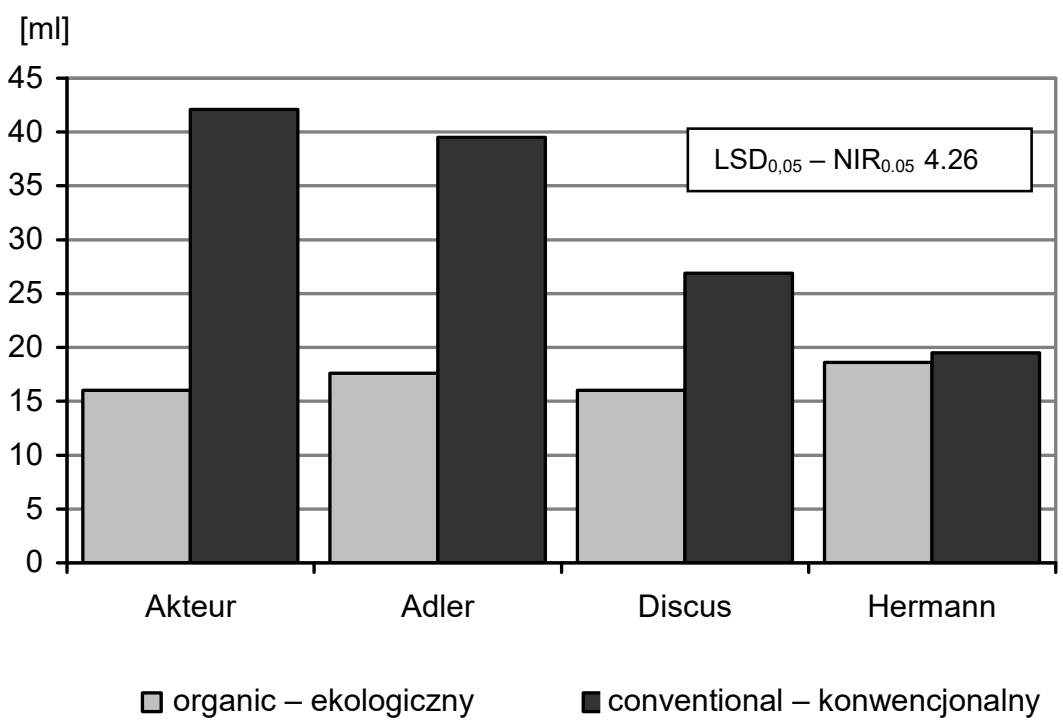

Fig. 1. The influence of cultivation system on rate of sedimentation of winter wheat Ryc. 1. Wpływ systemu uprawy na wskaźnik sedymentacji odmian pszenicy ozimej

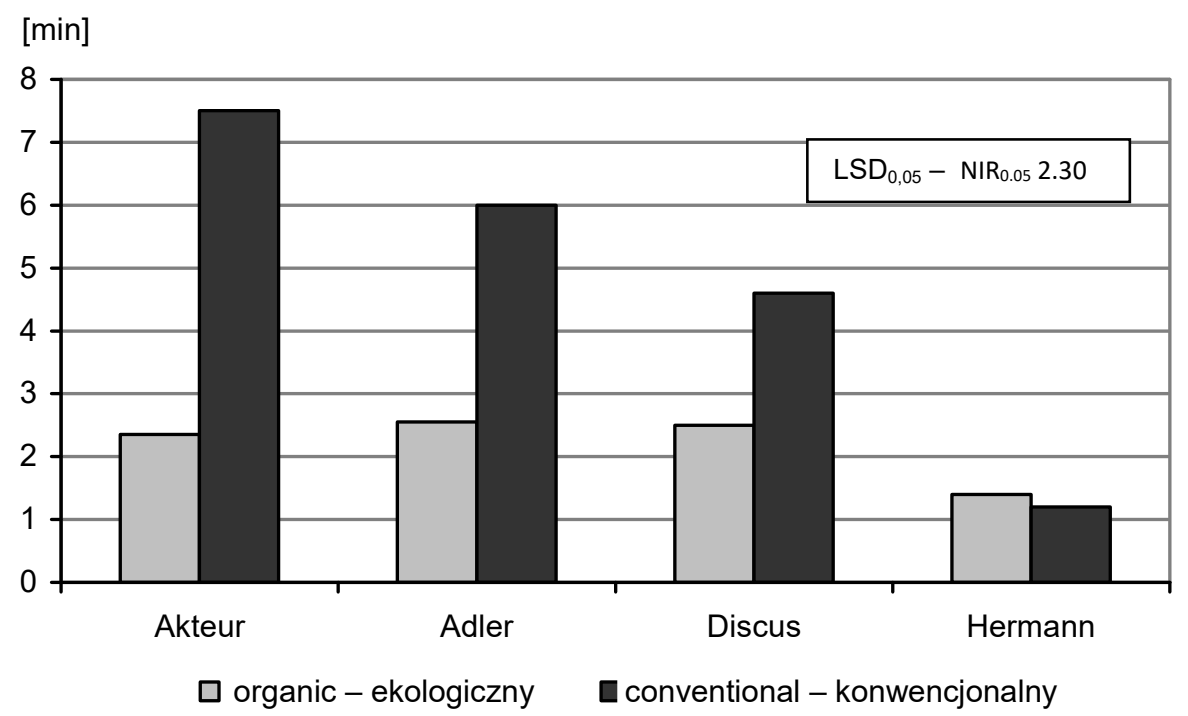

Fig. 2. The influence of cultivation system on stability of winter wheat Ryc. 2. Wpływ systemu uprawy na stabilność ciasta z odmian pszenicy ozimej 


\section{CONCLUSIONS}

1. The use of conventional and organic cultivation system had no significant effect on the physical properties of wheat grain. Significant differences were observed only in the case of 1000 grain weight.

2. Wheat grain obtained from conventional cultivation system was characterized by a better quality than grain from organic system. Significantly higher values were recorded for all quality characteristics except from sedimentation number and index gluten.

3. Farinographic features of dough improved due to the use of conventional cultivation system. An exception was the water absorption of flour, for which there was no statistically proven difference.

4. Akteur and Adler varieties were characterized by the best quality of grain and flour, while Hermann cv. - the worst.

\section{REFERENCES}

Adams M.L., Lombi E., Zhao F.J., McGrath S.P. 2002. Evidence of low selenium concentrations in UK bread-making wheat grain. J. Sci. Food Agr. 82, 1160-1165.

Alley M.M., Scharf P., Brann D.E., Harmmons J.L. 2009. Nitrogen management for winter wheat. Principles and recommendaions. Virginia Cooperative Extension, 1-6.

Al-Saleh A., Brennan Ch.S. 2012. Bread wheat quality: some physical, chemical and rheological characteristics of Syrian and English bread wheat samples. Foods 1, 3-17.

Budzyński W., Borysewicz J., Bielski S. 2004. Wpływ poziomu nawożenia azotem na plonowanie i jakość technologiczną ziarna pszenicy ozimej [The influence of nitrogen fertilization on yield and technological quality of winter wheat]. Pamięt. Puł. 135, 33-44. [in Polish]

Cacak-Pietrzak G., Ceglińska A., Jończyk K. 2014. Wartość wypiekowa mąki z ziarna odmian pszenicy uprawianych w ekologicznym systemie produkcji [Value of baking flour wheat variety with grain grown the organic system of production]. Zesz. Probl. Postęp. Nauk Rol. 576, 23-32. [in Polish]

Cacak-Pietrzak G., Gondek E., Jończyk K. 2013. Porównanie struktury wewnętrznej oraz właściwości przemiałowych ziarna orkiszu i pszenicy zwyczajnej z uprawy ekologicznej [Comparison of internal structure and milling properties of spelt and bread wheat from ecological farming]. Zesz. Probl. Postęp. Nauk Rol. 574, 3-10. [in Polish]

Ceglińska A., Cacak-Pietrzak G., Sobczyk M., Salwa M. 2012. Wpływ przechowywania mąki pszennej na wartość wypiekową [The influence of the storage wheat flour on baking value]. Zesz. Probl. Postęp. Nauk Rol. 571, 29-37. [in Polish]

Ceglińska A., Haber T., Cacak-Pietrzak G., Zmysłowska A. 2006. Dojrzewanie mąki pszennej a jakość pieczywa [The maturation of wheat flour and bread quality]. Prz. Zboż.-Młyn. 50(4), 20-21. [in Polish]

Chrzanowska-Drożdż B., Gil Z., Liszewski M., Malarz W. 2004. Wysokość i jakość plonu pszenicy ozimej w zależności od dawki i sposobu nawożenia azotem [Yield and quality of winter wheat depending on the dose and method of nitrogen fertilization]. Biul. IHAR 233, 29-38. [in Polish]

Czubacka M., Rachoń L. 2012. Wpływ poziomu agrotechniki na skład chemiczny ziarna pszenicy ozimej [The impact of the level of agricultural technology on the chemical composition of winter wheat grain]. Episteme 15, 45-52. [in Polish]

Harasim E., Wesołowski M. 2013. Wpływ retardanta Modus 250 EC i nawożenia azotem na plonowanie i jakość ziarna pszenicy ozimej [The effect of retardant Moddus $250 \mathrm{ec}$ and nitrogen fertilization on yielding and grain quality of winter wheat]. Fragm. Agron. 30(3), 70-77. [in Polish] 
Kasprzak M., Wirkijowska A. 2013. Charakterystyka wybranych wskaźników technologicznych ziarna pszenicy zwyczajnej [Characteristics of selected indicators of technological value of wheat grain]. Acta Agrophys. 20(1), 77-89. [in Polish]

Kihlberg I., Johansson L., Kohler A., Risvik E. 2004. Sensory qualities of whole wheat pan bread influence of farming system, miling and baking technique. J. Cereal Sci. 39, 67-84.

Knapowski T., Ralcewicz M., Spychaj-Fabisiak E., Lożek O. 2010. Ocena jakości ziarna pszenicy ozimej uprawianej w warunkach zróżnicowanego nawożenia azotem [Grain quality evaluation in winter wheat grown as exposed to varied nitrogen fertilization]. Fragm. Agron. 27(1), 73-80. [in Polish]

Kocoń A. 2005. Nawożenie jakościowe pszenicy jarej i ozimej a plon i jakość ziarna [Fertilization of quality spring and winter wheat and its impact on yield and grain quality]. Pamięt. Puł. 139, 55-64. [in Polish]

Kong L., Si J, Zhang B., Feng B., Li S., Wang F. 2013. Enviromental modification of wheat grain protein accumulation and associated processing quality: a case study of China. Aust. J. Crop Sci. 7(2), 173-181.

Krawczyk P., Ceglińska A., Izdebska K. 2008a. Porównanie właściwości reologicznych ciasta i pieczywa otrzymanego z mąki orkiszu i pszenicy zwyczajnej [Comparing rheological properties of dough and quality of bread made of spelt and common wheat flours]. Żywn. Nauk. Technol. Jakość 4(59), 141-151. [in Polish]

Krawczyk P., Ceglińska A., Kardialik J. 2008b. Porównanie wartości technologicznej ziarna orkiszu z pszenicą zwyczajną [Comparing the technological value of spelt grains to common wheat grains]. Żywn. Nauk. Technol. Jakość 5(60), 43-51. [in Polish]

Krejčírová L., Capouchová I., Petr I., Biocanová E., Faměra O. 2007. The effect of organic and conventional growing systems on quality and storage protein composition of winter wheat. Plant Soil Environ. 53(11), 499-505.

Krejčírová L., Capouchová I., Petr J., Bicanová E. Kuapil R. 2006. Protein composition and quality of winter wheat from organic and conventional farming. Agriculture 93(4), 285-296.

Makowska A., Obuchowski W., Adler A., Sulewska H. 2008. Charakterystyka wartości przemiałowej i wypiekowej wybranych odmian orkiszu [Characteristics of the milling and baking selected varieties spelled]. Fragm. Agron. 1(97), 228-239. [in Polish]

Mazurkiewicz J. 2005. Porównanie jakości technologicznej pszenicy i żyta uprawianych w warunkach konwencjonalnych i gospodarstwa ekologicznego [Comparison of the technological quality of wheat and rye cultivated in conventional and ecological farm conditions]. Acta Agrophys. 6(3), 729-741. [in Polish]

Murawska B., Spychaj-Fabisiak E., Keutgen A., Wszelaczyńska E., Pobereżny J. 2014. Cechy technologiczne badanych odmian ziarna pszenicy ozimej uprawianych w warunkach Polski i Wielkiej Brytanii [Technological features of the tested varieties of winter wheat grown under Polish and UK]. Inż. Chem. 53(2), 096-098. [in Polish]

PN-EN ISO 520 : 2011E. Cereals and pulses - determination of the mass of 1000 grains.

PN-EN ISO 7971-1 : 2010P. Cereals - determination of bulk density, called mass per hectoliter. Part 1. Reference method.

PN-EN ISO 5223 : 2016-02E. Test sieves for cereals.

PN-EN ISO 3093 : 2010E. Wheat, rye and their flours, durum wheat and durum wheat semolina. Determination of the falling number according to Hagberg-Perten.

PN-EN ISO 20483 : 2014-02P. Cereals and pulses - determination of the nitrogen content and calculation of the crude protein content - Kjeldahl method.

PN-EN ISO 21415-2 : 2015-12E. Wheat and wheat flour. Gluten content. Part 2. Determination of wet gluten and gluten index by mechanical means.

PN-EN ISO 5529 : 2010E. Wheat - determination of the sedimentation index - Zeleny test.

PN-EN ISO 5530-1 : 2015-01. Wheat flour - physical characteristics of doughs. Part 1. Determination of water absorption and rheological properties using a farinograph. 
Podolska G. 2007. Kształtowanie cech jakościowych ziarna pszenicy poprzez technologię produkcji [The formation of the quality characteristics of wheat grain through production technology]. Stud. Rapor. IUNG-PIB 9, 55-64. [in Polish]

Podolska G., Krasowicz S., Sułek A. 2005a. Ocena ekonomiczna i jakościowa upraw pszenicy ozimej przy różnym poziomie nawożenia azotem [Economic and quality evaluation of winter wheat cultivation in relation to different nitrogen fertilization levels]. Pamięt. Puł. 139, 175-188. [in Polish]

Podolska G., Stankowski S., Podolski B. 2005b. Plonowanie i wartość technologiczna ziarna pszenicy ozimej w zależności od warunków glebowych [Grain yield and technological va lue of winter wheat grains depending on soil conditions]. Pamięt. Puł. 139, 189-200. [in Polish]

Rachoń L., Szumiło G. 2009. Comparison of chemical compostition of selected winter wheat species. J. Elementol. 14(1), 135-146.

Shewry P.R. 2009. Wheat. J. Exp. Bot. 6(60), 1537-1553.

Smatanová N., Lacko-Bartošová M. 2012. Baking quality of triticum aestivum I. cultivated in sustainable farming systems. Res. J. Agr. Sci. 44(1), 146-149.

Stankowski S., Smagacz J., Hury G., Ułasik S. 2008. Wpływ intensywności nawożenia azotem na jakość ziarna i mąki odmian pszenicy ozimej [Effect of nitrogen fertilization intensity on grain and flour quality of winter wheat cultivars]. Acta Sci. Pol., Agricultura 7(3), 105-114. [in Polish]

Stępniewska S. 2013. Zależność pomiędzy aktywnością enzymów amylolitycznych a cechami reologicznymi ciasta pszennego [Relationship between amylolytic activity and rheological properties of wheat dough]. Acta Agrophys. 20(3), 463-472. [in Polish]

Wacławowicz R., Parylak D., Śniady R. 2005. Następczy wpływ nawożenia organicznego oraz mineralnego azotowego na plonowanie oraz wybrane cechy jakościowe ziarna pszenicy jarej [Residual effect of organic and nitrogen fertilization on the yields and selected quality features of spring wheat grain]. Pamięt. Puł. Zesz. 139, 277-288. [in Polish]

Weber R. 2013. Wpływ sposobu uprawy roli i wysokości ścierni na cechy jakościowe ziarna wybranych odmian pszenicy ozimej [Influence of tillage system and stubble height on grain properties of selected winter wheat cultivars]. Nauka Przyr. Tech. 1(18), 1-10. [in Polish]

Woźniak A. 2006. Wpływ przedplonów na plon i jakość ziarna pszenicy ozimej [Effect of forecrops on the yield and quality of winter wheat grain]. Acta Sci. Pol., Agricultura 5(2), 99-106. [in Polish]

Woźniak A., Gontarz D. 2005. Wpływ zróżnicowanego udziału pszenicy ozimej w zmianowaniu i poziomu agrotechniki na cechy jakościowe ziarna [The influence of different participation of winter wheat in crop rotation and agrotechnical level on the quality of grain]. Biul. IHAR 237/238, 3-11. [in Polish]

Abstract. The research material were cultivars of winter wheat grain from field experiments conducted in 2009-2010 from the National Research Center of Mecklenburg and Western Pomerania (LFA) in Gülzow. The first factor was a system of farming (conventional, ecological) and the second factor was the cultivars of winter wheat (Akteur, Adler, Discus i Hermann). Determined physical properties of grain, quality properties and rheological properties determined on farinograph. The use of conventional and organic cultivation system had no significant effect on the physical properties of wheat grain. Winter wheat grain obtained from conventional cultivation system characterized by a better quality than a grain from ecological system. Significantly higher values were obtained for crude protein content, gluten content, gluten softness and rate of sedimentation except for the falling number and index gluten. Using the conventional system obtained a better farinograph properties compared to the ecological. The exception was the waterabsorpsion for which there wasn't significant differences. The best quality of grain and flour characterized by a cultivar Akteur and Adler but the worst cultivar Hermann. 